\title{
PERTANGGUNGJAWABAN HUKUM PENGURUS YAYASAN \\ TERHADAP RUMAH SAKIT YANG DIKELOLA OLEH YAYASAN \\ BERDASARKAN UNDANG-UNDANG NOMOR 44 TAHUN 2009 \\ TENTANG RUMAH SAKIT
}

\author{
Hernindyo Reinan Mahastoro \\ E-mail: reinan.madridista@gmail.com \\ Mahasiswa Fakultas Hukum Universitas Sebelas Maret \\ Albertus Sentot Sudarwanto \\ E-mail: alsentotsudarwanto@yahoo.com \\ Dosen Fakultas Hukum Universitas Sebelas Maret
}

\begin{abstract}
This article aims to examine the legal issues to find out the liability of the foundation trustee who manages a hospital. The research method uses non doctrinal research method or empirical research, which finding the secondary data at the beginning, later on proceeded to the primary data. Law Number 44 Year 2009 on Hospital emphasizes that explains that hospitals can be managed by a non-profit legal entity, Law Number 16 Year 2001 jo. Law Number 28 Year 2004 on Foundation emphasizes that foundation trustee is fully responsible for the management of the foundation for the interests and objectives of the foundation and has the right to represent the foundation both inside and outside the court. This study that the validity of hospital managed by foundation could be valid if referring to the Constitutional Court Decision Number: 38 / PUU-XI / 2013. It was found that Aria Sentra Medika Hospital is valid and the Fatmawati Foundation Trustee is the party charged with liability for hospital management.
\end{abstract}

Keyword: Foundation; Foundation Trustee; Hospital; Validity; Liability

\begin{abstract}
Abstrak
Artikel ini bertujuan mengkaji isu hukum untuk mengetahui pertanggungjawaban pengurus yayasan yang mengelola rumah sakit. Metodologi penelitian yang digunakan adalah metode penelitian non doktrinal atau penelitian Empiris, yaitu meneliti data sekunder pada awalnya, untuk kemudian dilanjutkan penelitian terhadap data primer di lapangan. Undang - Undang Nomor 44 Tahun 2009 tentang Rumah Sakit menjelaskan bahwa rumah sakit dapat dikelola oleh badan hukum nirlaba, Undang - Undang Nomor 16 Tahun 2001 jo. Undang - Undang Nomor 28 Tahun 2004 tentang Yayasan menegaskan bahwa pengurus yayasan bertanggung jawab penuh atas kepengurusan Yayasan untuk kepentingan dan tujuan yayasan serta berhak mewakili yayasan baik di dalam maupun di luar Pengadilan Hasil penelitian ini diketahui bahwa sahnya suatu rumah sakit yang dikelola oleh yayasan dapat dinyatakan sah jika merujuk pada Putusan Mahkamah Konstitusi Nomor : 38/PUU-XI/2013. Pada hasil penelitian, diketahui bahwa Rumah Sakit Aria Sentra Medika adalah sah dan pengurus Yayasan Fatmawati adalah pihak yang dibebankan pertanggungjawaban atas kepengelolaan rumah sakit.
\end{abstract}

Kata Kunci: Yayasan; Pengurus Yayasan; Keabsahan; Pertanggungjawaban 


\section{A. Pendahuluan}

Pentingnya kesehatan dan pelayanan kesehatan bagi tiap-tiap warga Negara serta banyaknya ketersediaan rumah sakit sebagai institusi pelayanan kesehatan memicu pemerintah untuk melahirkan undang-undang terkait hal ini, undang-undang ini memiliki salah satu fungsi untuk menjamin seluruh orang di Indonesia untuk mendapatkan pelayanan kesehatan yang layak dari rumah sakit. Sesuai dengan Pasal 34 Ayat (3) UUD NRI 1945, bahwa Negara bertanggung jawab atas penyediaan fasilitas pelayanan kesehatan dan fasilitas pelayanan umum yang layak (Nurul Habibah, 2010: 1). Lahirlah pelaksanaan amanat tersebut melalui undang-undang, yakni Undang-Undang Nomor 44 Tahun 2009 tentang Rumah Sakit. Undang-Undang Nomor 44 Tahun 2009 tentang Rumah Sakit selain berfungsi untuk memberikan pelayanan kesehatan bagi masyarakat secara paripurna juga mengatur tentang pengelolaannya, pengelolaan rumah sakit bergantung kepada jenis rumah sakitnya, terkait hal ini Undang-Undang Nomor 44 Tahun 2009 tentang Rumah Sakit mengklasifikasikan rumah sakit menjadi 2 (dua) macam yakni rumah sakit privat dan rumah sakit publik, dalam pengelolaannya rumah sakit privat hanya dapat dikelola oleh badan hukum yang dengan tujuan profit yang berbentuk Perseroan Terbatas (PT) atau Persero sedangkan rumah sakit publik hanya dapat dikelola oleh Pemerintah, Pemerintah Daerah, dan badan hukum yang bersifat nirlaba.

Fenomena yang terjadi di masyarakat sekarang adalah terkait pengelola rumah sakit yang mengatasnamakan rumah sakit publik tetapi praktiknya bersifat privat, dalam hal ini adalah yayasan yang dewasa ini sulit dibedakan dengan lembaga yang berorientasi laba, karena terdapat sejumlah yayasan yang dijadikan pelindung untuk menyiasati berbagai aktivitas di luar bidang-bidang yang semestinya. Artinya ada pergeseran orientasi pelayanan rumah sakit antara bentuk kelembagaan dengan manajemen pengelolaannya. Hal yang banyak terjadi adalah bentuk kelembagaan yayasan selaku pengelola menerapkan manajemen perusahaan sebagaimana layaknya Perseroan Terbatas (PT), padahal jika badan sosial layaknya yayasan menjalankan/membentuk badan usaha, tujuan utamanya bukanlah untuk mencari keuntungan melainkan untuk melaksanakan tujuan tertentu dalam bidang sosial, keagamaan, dan kemanusiaan yang bersifat nirlaba.

Badan hukum yang bersifat nirlaba, adalah badan hukum yang tidak bertujuan untuk mencari laba/keuntungan melainkan bertujuan untuk hal-hal yang bersifat sosial, contoh dari badan hukum yang bersifat nirlaba adalah Persyarikatan dan Yayasan. Persyarikatan termasuk dalam jenis perkumpulan, dan yayasan adalah salah satu entitas badan hukum yang eksis di Indonesia serta yang pada praktiknya banyak rumah sakit yang didirikan dan dikelola oleh yayasan. Yayasan secara hukum diatur pada Undang-Undang Nomor 28 Tahun 2004 tentang Perubahan Atas Undang-Undang Nomor 16 Tahun 2001, pada Pasal 1 dijelaskan bahwa yayasan adalah badan hukum yang terdiri atas kekayaan yang dipisahkan dan diperuntukkan untuk mencapai tujuan tertentu dibidang sosial, kagamaan, dan kemanusiaan yang tidak mempunyai anggota. Dalam menunjang pemenuhan tujuannya, yayasan dapat melakukan kegiatan usaha dengan cara mendirikan badan usaha dan/atau ikut serta dalam badan usaha. Rumah sakit adalah salah satu bentuk badan usaha yang bisa dimiliki oleh yayasan.

Yayasan yang mengelola rumah sakit, pada dasarnya harus tetap berpedoman kepada maksud dan tujuan dari yayasan itu sendiri, selain dari hal itu yayasan sebagai pengelola, 
diharuskan mengarahkan rumah sakit sesuai dengan amanat Undang-Undang Dasar Negara Republik Indonesia tahun 1945, Undang-Undang Nomor 44 Tahun 2009 tentang Rumah Sakit, Undang-Undang Nomor 28 Tahun 2004 tentang Perubahan Atas Undang-Undang Nomor 16 Tahun 2001 tentang Yayasan, serta peraturan - peraturan lain yang menyinggung tentang yayasan dan rumah sakit yang berlaku. Pendirian rumah sakit oleh yayasan, bentuk rumah sakit yang dikelola oleh yayasan, jenis rumah sakit yang dikelola oleh yayasan, dan penerbitan izin operasional rumah sakit adalah sebagian ketentuan yang harus ditaati oleh yayasan dalam pendirian dan pengelolaan rumah sakit, bila ditemukan adanya penyelewengan terhadap ketentuan - ketentuan yang telah berlaku terdapat sanksi yang harus diterima oleh yayasan dan/atau rumah sakit terkait. Persyarikatan Muhammadiyah adalah salah satu contoh badan hukum nirlaba yang mendirikan serta mengelola rumah sakit. Persyarikatan Muhammadiyah memiliki dan mengelola 275 (dua ratus tujuh puluh lima) rumah sakit yang tersebar di 20 provinsi di wilayah kedaulatan Republik Indonesia, yang mana seluruhnya telah ada dan berdiri sebelum Undang-Undang Nomor 44 Tahun 2009 tentang Rumah Sakit diberlakukan. Terdapat ketentuan yang mengganjal keberjalanan rumah sakit yang didirikan dan dikelola oleh yayasan/badan hukum nirlaba pada Undang-Undang Nomor 44 Tahun 2009 tentang Rumah Sakit, yakni terkait ketentuan mengenai bentuk serta kegiatan usaha yang dilakukan oleh rumah sakit dan sanksi - sanksi yang akan diterapkan apabila melanggar ketentuan yang dimohonkan. Didasari atas ganjalan tersebut, Persyarikatan Muhammadiyah melayangkan permohonan judicial review kepada Mahkamah Konstitusi Republik Indonesia 4 (empat) tahun setelah Undang-Undang Nomor 44 Tahun 2009 tentang Rumah Sakit diberlakukan, hasil dari permohonan judicial review adalah Putusan Mahkamah Konstitusi Nomor: 38/ PUU-IX/2013 yang mengabulkan sebagian permohonan dari Persyarikatan Muhammadiyah.

Yayasan Fatmawati adalah suatu badan hukum nirlaba yang memiliki tujuan pada bidang sosial, yayasan ini berdiri sejak tahun 1953. Sejak terbentuknya yayasan yang awalnya bernama Jajasan Ibu Soekarno, badan hukum ini selalu bertujuan pada bidang sosial dan konsisten dalam kepemilikan badan usaha berupa rumah sakit. Rumah sakit yang dikelola oleh Yayasan Fatmawati ialah Rumah Sakit Aria Sentra Medika, Rumah sakit tersebut sebelumnya bernama Rumah Sakit RP Soeroso kala masih dikelola oleh Jajasan Ibu Soekarno. Rumah sakit ini berkedudukan di Pamulang, Tangerang Selatan, Banten. Berdasarkan uraian yang telah disampaikan, artikel ini akan membahas mengenai pertanggungjawaban hukum dari pengurus Yayasan Fatmawati yang mengelola Rumah Sakit Aria Sentra Medika.

\section{B. Metode Penelitian}

Metode penelitian yang digunakan adalah penelitian hukum non doctrinal yang disebut juga penelitian hukum empiris dan bersifat deskriptif. Pendekatan penelitian ini bersifat kualitatif yaitu menggunakan data yang dinyatakan secara verbal. Lokasi penelitian ini pada Yayasan Fatmawati di Jakarta dan Rumah Sakit Aria Sentra Medika di Tangerang Selatan.

\section{Hasil Penelitian dan Pembahasan}

Banyaknya bentuk tanggung jawab menyebabkan sulitnya merumuskan dalam bentuk kata - kata yang sederhana dan mudah dimengerti, namun jika diamati lebih jauh maka tanggung jawab selalu berkisar pada kesadaran untuk melakukan, kesediaan untuk melakukan, dan kemampuan untuk melakukan. Dalam budaya kita, umumnya tanggung jawab diartikan 
sebagai keharusan untuk "menanggung" dan "menjawab" dalam pengertian lain yaitu suatu keharusan untuk menanggung akibat yang ditimbulkan dari suatu perilaku dalam ranka menjawab suatu persoalan (Nur Hidayah, Ramli Siregar, dan Windha. Jurnal Transparency. Vol. II No. 1, Juni 2013: 7). Pertanggungjawaban merupakan tindakan dimana seseorang yang telah melakukan kesalahan atas perbuatannya, lalu orang tersebut diminta untuk menyadari atas kesalahannya dan memperbaiki akibat dari perbuatannya (Dony Setiawan Putra. Jurnal Hukum Magnum Opus. Vol. II No. 2, Februari 2019: 94).

Rumah sakit memiliki tanggung jawab publik untuk menyelenggarakan pelayananan kesehatan yang bermutu dan terjangkau berdasarkan prinsip aman, menyeluruh, non diskriminatif, partisipatif dan memberikan perlindungan bagi masyarakat sebagai pengguna jasa layanan kesehatan (Nadya Said. Jurnal Ilmu Hukum Legal Opinion. Vol. 4 No. 4, 2016: 16), Pertanggungjawaban hukum dari kepengurusan rumah sakit dapat ditinjau dari pembidangan hukum itu sendiri, jika pertanggungjawaban hukum ditinjau berdasarkan hukum perdata maka unsur terkait adalah ada tidaknya suatu perbuatan melawan hukum atau wanprestasi (Arrie Budhiartie. Jurnal Penelitian Universitas Jambi Seri Humaniora. Vol. 11 No. 2, Juli - Desember 2009: 47).

Yayasan adalah subjek hukum, tetapi bukanlah makhluk hidup seperti manusia, melainkan badan hukum, yayasan tidak dapat melakukan perbuatan hukum sendiri (Nur Hidayah, Ramli Siregar, dan Windha. Jurnal Transparency. Vol. II No. 1, Juni 2013: 4). Perbuatan hukum dari yayasan timbul dari tindakan pengurus selaku organ yang melaksanakan kepengurusan dari yayasan, maka untuk mengetahui pertanggungjawaban suatu yayasan, perlu diketahui tentang pertanggungjawaban pengurus. Untuk mengetahui pertanggungjawaban pengurus Yayasan Fatmawati terhadap Rumah Sakit Aria Sentra Medika maka harus diketahui terlebih dahulu tindakan - tindakan yang dilakukan oleh pengurus Yayasan Fatmawati terhadap Rumah Sakit Aria Sentra Medika. Tindakan dari pengurus berpedoman pada kewajiban yang dimiliki, UUY mencantumkan kewajiban - kewajiban yang harus dipenuhi oleh organ pengurus dari yayasan. Kewajiban pengurus tercantum pada Pasal 35 UUY yang berbunyi:

1. Pengurus Yayasan bertanggung jawab penuh atas kepengurusan Yayasan untuk kepentingan dan tujuan Yayasan serta berhak mewakili Yayasan baik di dalam maupun di luar Pengadilan.

2. Setiap Pengurus menjalankan tugas dengan itikad baik, dan penuh tanggung jawab untuk kepentingan dan tujuan Yayasan.

3. Dalam menjalankan tugas sebagaimana dimaksud dalam ayat (2), Pengurus dapat mengangkat dan memberhentikan pelaksana kegiatan Yayasan.

4. Ketentuan mengenai syarat dan tata cara pengangkatan dan pemberhentian pelaksana kegiatan Yayasan diatur dalam Anggaran Dasar Yayasan.

5. Setiap Pengurus bertanggung jawab penuh secara pribadi apabila yang bersangkutan dalam menjalankan tugasnya tidak sesuai dengan ketentuan Anggaran Dasar, yang mengakibatkan kerugian Yayasan atau pihak ketiga.

Pengurus tidak diperbolehkan melakukan beberapa hal, ketentuannya tercantum pada Pasal 38 UUY yakni:

1. Pengurus dilarang mengadakan perjanjian dengan organisasi yang terafiliasi dengan Yayasan, Pembina, Pengurus, dan/atau Pengawas Yayasan, atau seseorang yang bekerja pada Yayasan. 
2. Larangan sebagaimana dimaksud dalam ayat (1) tidak berlaku dalam hal perjanjian tersebut bermanfaat bagi tercapainya maksud dan tujuan Yayasan.

Pengurus diharuskan cermat dalam segala tindakannya yang berkaitan dengan yayasan, karena apabila tindakan dari pengurus menyebabkan kepailitan suatu yayasan, terdapat akibat yang sudah ditentukan pada Pasal 39 UUY yakni:

1. Dalam hal kepailitan terjadi karena kesalahan atau kelalaian Pengurus dan kekayaan Yayasan tidak cukup untuk menutup kerugian akibat kepailitan tersebut, maka setiap Anggota Pengurus secara tanggung renteng bertanggung jawab atas kerugian tersebut.

2. Anggota Pengurus yang dapat membuktikan bahwa kepailitan bukan karena kesalahan atau kelalaiannya tidak bertanggung jawab secara tanggung renteng atas kerugian sebagaimana dimaksud dalam ayat (1)

3. Anggota Pengurus yang dinyatakan bersalah dalam melakukan pengurusan Yayasan yang menyebabkan kerugian bagi Yayasan, masyarakat, atau Negara berdasarkan putusan pengadilan, maka dalam jangka waktu 5 (lima) tahun terhitung sejak tanggal putusan tersebut memperoleh kekuatan hukum yang tetap, tidak dapat diangkat menjadi Pengurus Yayasan manapun.

Pengurus yayasan adalah bagian yang penting pada tubuh yayasan, karena yayasan tidak diperbolehkan untuk memiliki anggota sehingga susunan pengurus adalah pihak yang berpotensi kuat untuk menentukan tindakan dari yayasan, Yayasan Fatmawati selaku pendiri dan pengelola dari Rumah Sakit Aria Sentra Medika, selain tunduk pada UUY juga harus patuh pada ketentuan UURS. Kepengelolaan rumah sakit diatur dalam UURS, seperti yang sudah disinggung sebelumnya, Rumah Sakit Aria Sentra Medika adalah rumah sakit publik karena dikelola badan hukum yang bersifat nirlaba. Adapun ketentuan penyelenggaraan rumah sakit terdapat pada Pasal 33 UURS yang berbunyi,

1. Setiap Rumah Sakit harus memiliki organisasi yang efektif, efisien, dan akuntabel.

2. Organisasi Rumah Sakit paling sedikit terdiri atas Kepala Rumah Sakit atau Direktur Rumah Sakit, unsur pelayanan medis, unsur keperawatan, unsur penunjang medis, komite medis, satuan pemeriksaan internal, serta administrasi umum dan keuangan.

Syarat dari pengisi organisasi kepengelolaan rumah sakit tercantum pada Pasal 34 UURS yang berbunyi sebagai berikut,

1. Kepala Rumah Sakit harus seorang tenaga medis yang mempunyai kemampuan dan keahlian di bidang perumahsakitan.

2. Tenaga struktural yang menduduki jabatan sebagai pimpinan harus berkewarganeraan Indonesia.

3. Pemilik Rumah Sakit tidak boleh merangkap menjadi kepala Rumah Sakit.

Ketentuan pada Pasal 34 ayat (3) UURS memperkuat ketentuan yang tercantum pada Pasal 7 ayat (3) UUY yang berbunyi, "Anggota Pembina, Pengurus, dan Pengawas Yayasan dilarang merangkap sebagai Anggota Direksi atau Pengurus dan Anggota Dewan Komisaris atau Pengawas dari badan usaha sebagaimana dimaksud dalam ayat (1) dan ayat (2)". Berdasarkan penuturan Dwi Librianto, pengurus Yayasan Fatmawati tidak secara langsung terlibat dalam kepengelolaan Rumah Sakit Aria Sentra Medika, pengurus yayasan membentuk kepengurusan sendiri untuk mengelola Rumah Sakit Aria Sentra Medika yang berbentuk organisasi, organisasi ini bukan merupakan badan hukum. Organisasi pengelola rumah sakit diartikan sebagai pelaksana kegiatan dari Yayasan Fatmawati, pelaksana kegiatan dapat 
diartikan sebagai entitas yang menjalankan kegiatan yayasan yang tidak bisa dijalankan oleh pengurus atau organ lain dari yayasan

Organisasi pengelola rumah sakit selaku pelaksana kegiatan dari Yayasan Fatmawati melalui Rumah Sakit Aria Sentra Medika memiliki jangka waktu 5 (lima) tahun dan dapat diangkat kembali sebagai anggota organisasi pengelola, bertanggung jawab kepada pengurus Yayasan Fatmawati, dan menerima gaji atas sumbangsihnya pada Rumah Sakit Aria Sentra Medika. Dwi Librianto menjelaskan bahwa organisasi pengelola Rumah Sakit Aria Sentra Medika menjalankan fungsi dan tugas sehari - hari operasional Rumah Sakit Aria Sentra Medika dengan kewenangan penuh, namun dalam hal pengangkatan karyawan, membuat kontrak - kontrak, dan pembelian perangkat perumahsakitan dibutuhkan surat penugasan yang diterbitkan oleh organ pengurus yayasan. Djenny Suharso menambahkan bahwa urusan secara internal secara penuh didelegasikan penuh kepada organisasi pengelola rumah sakit baik itu medis ataupun nonmedis, sedangkan urusan secara eksternal yang berkaitan dengan pihak ketiga adalah kewenangan dari pengurus yang dapat didelegasikan.

Pertanggungjawaban hukum yang diemban oleh pengurus Yayasan Fatmawati adalah pertanggungjawaban hukum perdata, karena memang .pada awalnya Yayasan Fatmawati selaku pendiri Rumah Sakit Aria Sentra Medika adalah badan hukum yang sah bertindak secara hukum. Pengurus yayasan juga yang dalam rapat pengurus mengeluarkan keputusan yang dapat memicu perbuatan hukum yang beresiko menimbulkan akibat hukum. Hal pertanggungjawaban perdata dapat dibebankan pada organisasi pengelola apabila dalam menjalankan fungsinya sebagai subjek hukum, organisasi pengelola tidak bekerja berdasarkan surat penugasan ataupun tanpa surat penugasan sehingga pengurus yayasan yang tidak mengetahui perbuatan hukum yang dilakukan dapat dilepaskan dari beban pertanggungjawaban hukum perdata.

\section{Simpulan}

Berdasarkan penjelasan hasil penelitian dan pembahasan, maka dapat disimpulkan bahwa Pengurus Yayasan Fatmawati adalah pihak yang bertanggungjawab dari akibat hukum yang ditimbulkan jika muncul persoalan hukum keperdataan yang menyangkut Rumah Sakit Aria Sentra Medika, sebab organisasi pengelola Rumah Sakit Aria Sentra Medika bukan subjek hukum yang dapat mengemban pertanggungjawaban dari persoalan hukum keperdataan.

\section{E. Saran}

Pemerintah Cq. Menteri Kesehatan seharusnya menerbitkan peraturan yang mewajibkan organisasi pengelola rumah sakit berbentuk badan hukum, hal ini diperlukan karena tidak semua rumah sakit berbentuk badan hukum, kepastian hukum dari rumah sakit yang bukan badan hukum menjadi bias menuju badan hukum nirlaba yang mengelolanya, sedangkan organ dari badan hukum nirlaba tidak boleh turut serta secara langsung mengelola badan usahanya dan belum tentu menguasai bidang - bidang keahlian yang dibutuhkan pada badan usahanya.

Organisasi pengelola rumah sakit perlu mencermati ketentuan - ketentuan kepengelolaan rumah sakit yang ada pada UURS agar terjadi kesinambungan kepengelolaan dengan pendiri rumah sakit yang baik, efektif, dan efisien. 


\section{F. Daftar Pustaka}

\section{Buku}

Arie Kusumastuti Maria Suhardiadi. 2002. Hukum Yayasan di Indonesia Berdasarkan UndangUndang Republik Indonesia Nomor 16 Tahun 2001 tentang Yayasan. Jakarta: Penerbit PT. Abadi.

H.B. Sutopo. 2010. Pengantar Metodologi Penelitian Kualitatif. Surakarta: UNS Press.

\section{$\underline{\text { Jurnal }}$}

Arrie Budhiartie. 2009. "Pertanggungjawaban Hukum Perawat Dalam Penyelenggaraan Pelayanan Kesehatan Di Rumah Sakit”. Jurnal Penelitian Universitas Jambi Seri Humaniora. Volume 11 Nomor 2. Jambi: Fakultas Hukum Universitas Jambi.

Bagus Adi Nugroho dan Albertus Sentot Sudarwanto. 2018. "Pengelolaan Rumah Sakit Berbentuk Perseroan Terbatas Berdasarkan Tinjauan Filosofis Dan Yuridis”. Jurnal Repertorium. Volume 5 Nomor 1. Surakarta: Fakultas Hukum Universitas Sebelas Maret.

Dani Amalia Arifin. 2016. "Kajian Yuridis Tanggung Jawab Perdata Rumah Sakit Akibat Kelalaian Dalam Pelayanan Kesehatan”. Jurnal Idea Hukum. Volume 2 Nomor 1. Purwokerto: Fakultas Hukum Universitas Jenderal Soedirman.

Dony Setiawan Putra. 2019. "Pertanggungjawaban Pidana Rumah Sakit Sebagai Perseroan Terbatas Dalam Kasus Jual Beli Manusia”. Jurnal Hukum Magnum Opus. Volume II Nomor 2. Surabaya: Fakultas Hukum Universitas 17 Agustus 1945.

Nadya Said. 2016. "Hubungan Hukum Antara Pasien Dan Tenaga Medis Serta Rumah Sakit". Jurnal Ilmu Hukum Legal Opinion. Volume 4 Nomor 4. Palu: Fakultas Hukum Universitas Tadulako.

Nur Hidayah, Ramli Siregar, dan Windha. 2013. "Pertanggungjawaban Organ Yayasan Atas Pailitnya Yayasan Menurut Undang-Undang Nomor 16 Tahun 2001 Jo Undang-Undang Nomor 28 Tahun 2004 Tentang Yayasan". Jurnal Transparency. Volume II Nomor 1. Medan: Fakultas Hukum Universitas Sumatera Utara.

Y. Sogar Simamora. 2018. "Karakteristik, Pengelolaan Dan Pemeriksaan Badan Hukum Yayasan Di Indonesia”. Jurnal Rechtsvinding. Volume 1 Nomor 2. Jakarta: Badan Pembinaan Hukum Nasional Kementerian Hukum dan Hak Asasi Manusia Republik Indonesia. 